\title{
Developing an Index of Media Innovation in a National Market
}

\section{José A. García-Avilés, Miguel Carvajal-Prieto, Alicia De Lara-González \& Félix} Arias-Robles

To cite this article: José A. García-Avilés, Miguel Carvajal-Prieto, Alicia De Lara-González \& Félix Arias-Robles (2016): Developing an Index of Media Innovation in a National Market, Journalism Studies, DOI: 10.1080/1461670X.2016.1161496

To link to this article: http://dx.doi.org/10.1080/1461670X.2016.1161496

\section{曲 Published online: 24 Mar 2016.}

Submit your article to this journal $\sqsubset$

\section{山 Article views: 3}

\section{Q View related articles $ᄃ$}

View Crossmark data $\nearrow$ 


\title{
DEVELOPING AN INDEX OF MEDIA INNOVATION IN A NATIONAL MARKET The case of Spain
}

\author{
José A. García-Avilés, Miguel Carvajal-Prieto, Alicia De \\ Lara-González, and Félix Arias-Robles
}

\begin{abstract}
From a global vision of journalism innovation, this article presents a matrix that analyses and measures an innovation index of market-specific media initiatives, providing a valuable tool for comparative analysis. A method has been designed that consists of (1) sample collection and selection, and (2) the quantitative and qualitative analysis of each innovation identified in the cases studied. With the aim of generating an Index of Media Innovation, 25 of the most innovative cases within the field of reference in Spain were studied during the period 2013-2014 through a database consisting of 196 innovations that were analysed as a function of area, degree and technological basis. The results indicate that, in Spain, journalism innovation occurs at the margins of the traditional news industry and, for the most part, innovation is expanding among digital native media outlets, niche initiatives and start-ups.
\end{abstract}

KEYWORDS innovation; innovation index; journalism; online media; Spain

\section{Introduction}

The technological and industrial changes experienced by the media in recent years have raised important practical and theoretical questions in journalism. The strengthening of new media companies has intensified the sector's transformation (Bruno and Nielsen 2012; Franklin 2014; Carlson and Usher 2015). As Anderson, Bell, and Shirky (2012) argue, this disruptive change has weakened the traditional media industry, generating a new post-industrial paradigm more dependent than before on technological agents (Cardoso and Moreno 2015). Innovation has, therefore, become "a crucial asset to the survival of the media industry" (Weiss and Domingo 2010, 3 ) and an aspect that media enterprises increasingly value (Küng 2013).

Thus, media outlets have no choice but to transform themselves and "act strategically in improving their editorial processes and products, as well as their business models and organizational structures" (Westlund and Lewis 2014, 11). Although certain legacy media enterprises appear reluctant to innovate (Nguyen 2008), others are developing strategies to face up to the industry's disruptive changes, as indicated by The New York Times' $(2014,1)$ Innovation Report and the British Broadcasting Corporation's (2015) Future of News report. Moreover, local media outlets are attempting to innovate in order to face the creative and economic challenges that exist in their competitive sectors (van Kerkhoven and Bakker 2014).

In this context, innovation has emerged as a term that addresses phenomena of varying natures, since it has a cross-cutting influence on various fields of sociology and 
practical and theoretical journalism. Both the vision and the practice of innovation have an impact on the competitiveness of media companies and the development of the sector (Christensen, Skok, and Allworth 2012). It is relevant, therefore, to study how and to what degree current innovation manifests itself in the media and in the new industrial stage in which it is unfolding. From an industrial perspective, innovation can be measured and it is regarded as a key factor for economic growth, as demonstrated by academic tradition (Schumpeter 1975) and leading institutions such as the Oslo Manual (OECD 2005) and the Community Innovation Survey (Eurostat 2012). However, innovation in the media industry cannot be reflected precisely, since the evaluation methods used in most indices "do not properly capture the innovativeness" (Bleyen et al. 2014, 30). Given the complex nature of the media, innovation needs to be addressed through a global vision that considers journalism as a process, product and service.

The aim of this article is to show where and how innovation emerges within the Spanish media sector within a specific timeframe. In addition to the results, we present a method that aims to respond to the main concerns outlined. Based on a concept of innovation that defines the subsequent qualitative analysis, we define the areas in which innovation occurs following a review of other proposals and we also evaluate the degree of change brought about by each innovation within the area of study. In order to carry out comparative studies, this method of analysis could be adapted to studies in other countries.

\section{Theoretical Framework of Media Innovation}

Research into media innovation has grown notably in recent years reflecting the transformation of the industrial and technological context. The interest generated by media innovation is reflected in the various reviews of specialised literature (Dogruel 2013; Storsul and Krumsvik 2013; Bleyen et al. 2014; Bruns 2014; Westlund and Lewis 2014; Carvajal et al. 2015). In recent years, authors have analysed this subject in depth from various perspectives: media management (Dal Zotto and Kranenburg 2008; Baumann 2013), new technologies and services (Spyridou et al. 2013; Dogruel 2014), relations with the "social audience" (Bruns 2014) and emerging business models (Carvajal, García-Avilés, and González 2012). In these areas, innovation does not need to limit itself to a product, technology or new content, but can base itself on a novel combination of previously existing ideas, processes and resources (Storsul and Krumsvik 2013).

Media industry and management studies have been conducted from a perspective of creative destruction (Schumpeter 1975; cf. Fagerberg 2004) and confirm how advances in technology are displacing incumbent companies because smaller and more agile enterprises develop revolutionary products and processes (Christensen 1997; Christensen, Skok, and Allworth 2012; Nee 2013). According to observations of those media outlets that have implemented innovative strategies, innovation entails the remodelling of productive processes (Westlund and Krumsvik 2014) and effective management-based communication through projects that put people and resources at the service of processes, and not the reverse (García-Avilés 2012). Therefore, research into media innovation requires a multidisciplinary approach that combines qualitative and quantitative methods within a broad study area (Krumsvik and Storsul 2013; Bleyen et al. 2014).

Media innovation occurs through "mutations" in areas related to technology, communication and organisation (Boczkowski 2004, 11). Based on Boczkowski's study, Steensen (2009) underlines that work culture, management, the adequate use of technology and the 
initiative of some journalists also impact on the degree of innovation. This involves focusing not only on products, but also on the processes that create these products and that are able to tangibly and intangibly incorporate innovations (Dogruel 2014, 57-58). Siapera (2012) argues that change and innovation take place at three levels: organisation, contents and audience. Moreover, she also holds that success is not limited to innovative technological development; rather, it involves appropriate adaptation to the social, cultural, political and economic context. In this regard, Bleyen et al. $(2014,48)$ proposed a novel type of media innovation based on five categories: "Business model, production and distribution, consumption and media, inner form, and core".

Among the extensive literature available on innovation, we have found numerous attempts to reflect the multi-dimensional nature of the concept of innovation. Baregheh, Rowley, and Sambrook $(2009,1334)$ gathered more than 60 definitions from multi-disciplinary bibliographies to produce a concise definition that resonates with the perspective of this study: "Innovation is the multi-stage process whereby organizations transform ideas into new/improved products, service or processes, in order to advance, compete and differentiate themselves successfully in their marketplace". Similarly, O'Sullivan and Dooley (2008) approach innovation as a process that generates value for the company. Moreover, they distinguish the degree of change, which is in line with our study:

Innovation is the process of making changes, large and small, radical and incremental, to products, processes, and services that results in the introduction of something new for the organization that adds value to customers and contributes to the knowledge store of the organization. (O'Sullivan and Dooley 2008, 5)

From this review of the literature, we consider media innovation to be the capacity to react to changes in products, processes and services through the use of creative skills that allow a problem or need to be identified, and to solve it through a solution that results in the introduction of something new that adds value to customers and to the media organisation.

Having defined media innovation, we will present a method that provides a series of indicators that allow the degree of innovation of media initiatives in a specific reference market to be measured and quantified. This method, having been tested and refined at the experimental level, was applied to the Spanish market with the aim of creating an index of the most innovative media outlets in Spain during the period 2013-2014. It is pertinent, therefore, to know the context of this market before detailing our research.

\section{An Overview of the Evolution of Innovation in the Spanish Media (1995-2015)}

Innovation in digital media in Spain parallels in many ways the trajectory taken by the development of online journalism. Briefly, digital media process and product innovation can be grouped into three broad periods: (1) passive introduction (1996-2001); (2) active adaptation (2002-2008); and (3) disruptive emancipation (2009-2015).

The "passive introduction" phase (1996-2001) was characterised by the slow implementation of the internet in editorial offices in a context of low digital penetration among readers. During this period, the innovations were, logically, experimental answers to the novelty of channels and formats and the appearance of the "user" where before there had only been readers. In 2005, 1274 online media outlets were active in Spain (Salaverría 2005, 18). Some of them fostered direct contact with readers, using various 
tools such as online chats and discussions. A few of the media outlets even offered customised content as the technological possibilities that provided digital support developed.

Between 2001 and 2008, Spanish media innovation underwent a second stage of "active adaptation", showing a greater interest in online support by the traditional media, although it played a somewhat secondary role to the outlets' main task. Many media outlets went through a phase of "portalization" of their websites, in which their main aim was to become a gateway to a multitude of in-house and external services. This phase was characterised by the aligning of formats and channels as a result of improvements in the websites of commercial television stations. Large media groups, such as Prisa, Vocento and Unidad Editorial, introduced innovations into their products and newsrooms in order to adapt to the new environment. Radio stations also strengthened their strategies to attract new audiences and improve participation through online tools, but with the spotlight on analogue broadcasting. This phase was also noted for adaptations in media format as a response to external trends, such as the increasing use of blogs and specialisation, foremost of which was the appearance of digital native opinion media outlets, which differentiated themselves by publishing rumours and off-the-record comments.

The end of this period saw the maturing of the online media sector with innovations typified by (1) the rupture of the time and spatial limitations of news products; (2) the hybridisation of formats and multimedia narratives; and (3) users' involvement through product customisation. From an organisational point of view, multimedia groups implemented adaptive innovations to manage corporate convergence strategies by implementing various levels of newsroom integration (López and Pereira 2010).

The media industry then went through a final stage of "disruptive emancipation" (2008-2015) characterised by the appearance of innovations linked to the birth of new media projects. As a result of the crisis in the legacy media, 450 new media projects have emerged in Spain since 2008, mainly digital platforms promoted by journalists themselves (APM 2015). According to this same source, more than 12,000 journalists lost their jobs in traditional media between 2008 and 2014. Some of the most innovative projects were launched specifically by unemployed journalists who invested in enterprise formats in specialised or hyperlocal media. Editors started using coded algorithms, explored new ways of viewing news and attempted to innovate in the use of interactivity and newsroom organisation.

The traditional media and start-ups responded to the changes in reader habits with innovations (Llorens, Grau, and Luzón 2013). A gradual "socialisation" took place as a result of the increasing appearance of social networks. Some of the traditional media realised that they had to invest in digital channels as the primary space, giving rise to the first innovation laboratories. Emerging projects underwent a change of focus and content form and explored new forms of income generation and traditional media, particularly the printed press, introduced some improvements. However, innovation was virtually monopolised by the newly created media outlets. The boom in tablets favoured the exploration of new formats in news content and advertising marketing. In terms of organisation, new entities, including cooperatives and foundations, began to appear in which reporters or readers became media owners.

The legacy media underwent frequent changes, including Web design, experimenting with new forms of digital distribution and launching spin-offs in order to attract a younger audience, whose appetite for news was in free-fall (Sádaba, García Avilés, and Martínez-Costa 2016). Digital native media invested more effort in getting subscribers, and innovations in user participation were introduced. This period finished in the same 
way it started, with the emergence of new purely digital players: in barely a month, El Español raised €3.6 million in its crowdfunding campaign before its launch in October 2015.

\section{Method}

This study has two basic aims:

1. To establish an analytical index, based on agreed and tested parameters, that measures the number and degree of innovations developed by a particular media outlet or media initiative.

2. To apply this index to a sample of cases from the Spanish sector with the aim of carrying out a comparative study of the most innovative media in this market during the selected time period.

To achieve these aims, it is important to establish four key factors that influence the measurement parameters (Carvajal et al. 2015): (1) the concept of innovation; (2) the area in which it takes place; (3) the degree of innovation; and (4) the technological basis. Following a review of the scientific and professional literature, we decided to opt for our previously proposed concept of media innovation.

Our approach was to analyse a unifying proposal based on a theoretical framework. This global vision assumes that media innovation influences the product (editorial content, formats, genres, etc.), services (of public and commercial interest), value chain processes (Bleyen et al. 2014; Robinson 2011) and the organisation of the agents of media innovations (Westlund and Lewis 2014). In this way, the proposed matrix is able to gather innovations that have occurred in the media process, the product and the organisation (Carvajal et al. 2015; Dogruel 2013). The various innovations, from our point of view, can be grouped into four areas of analysis: product, production and distribution processes, organisation and marketing. Moreover, these areas do not exclude those innovations lacking a technological basis (Bleyen et al. 2014).

The degree of innovation indicates the level of change brought about by that innovation within the organisation and product within the reference market during the indicated time period. In traditional Schumpeterian literature, there is general agreement that innovations can be either "radical" or "incremental" according to the degree of change they bring about in product or service value creation (Storsul and Krumsvik 2013). For this reason, in our classification we chose to distinguish between radical and incremental innovations, as explained further on. Finally, the index considers whether the innovation possesses a technological basis or not, such that novel features that go beyond the technological aspect can be included. If the innovation is related to a specific technology, it considers whether that technology has been developed by the enterprise itself or has been externally acquired.

The fieldwork was carried out in 2014 during two separate phases that are described in the next sections: (1) sample collection and selection; and (2) qualitative analysis and final evaluation.

\section{Sample Collection and Selection}

To collect samples, we employed the Delphi method, which is commonly used in various communications studies to gather expert opinion on, for example, interactive 
graphics in online media (Schroeder 2004), in studies on audiences and media consumption (van der Wurff and Schönbach 2014), on media innovation (García-Santamaría, Clemente, and López 2013) and the potential of social networks (Linke and Zerfass 2012). In this study, the Delphic method was carried out in various stages: formulation of the problem, selection of experts, planning of the survey on innovative initiatives, and, lastly, the analysis of the proposals.

A survey was carried out between April and May 2014 in which an email was sent to 20 experts selected for their subject knowledge with the aim of reflecting both the academic and industry perspective. The experts were selected from the following fields: audiences, entrepreneurship, new narratives, online journalism, business models, social media, marketing and media consultation. Each was asked to put forward a list of 10 Spanish media initiatives that, in their opinion, "were the most innovative". They were asked to look further than the category of "media" and were suggested the four areas of innovation studied here.

The experts' replies were grouped into a list containing 60 innovative media initiatives. A final sample of 25 most relevant cases was selected from these. To carry out the selection, a three-part filter was implemented: (1) social relevance; (2) professional relevance; and (3) expert relevance. Each of these variables was assigned 33 per cent of the overall evaluation.

To measure the social relevance of each media initiative, data on their audience and influence on social networks was recorded according to the procedure proposed by Napoli (2014). Firstly, the Alexa national ranking of each initiative's website in a particular week (in this case, the first week of September 2014) was determined. The number of followers on Twitter and Facebook fans of each website was recorded, also in the same reference period. To avoid the over-representation of the most popular sites, these initiatives were also assessed in terms of maintaining an active relationship with their followers on these social networks. For this, the ratio of the number of retweets versus the number of tweets published on Twitter was measured using Twitonomy ${ }^{1}$ and the ratio of engagement on Facebook was measured using Likealyzer, ${ }^{2}$ which indicates the average number of shared comments and posts. Each of the recordings was assigned a specific weighting according to the following formula: Spanish Alexa ranking (20 per cent) + Twitter followers (15 per cent) + Retweets ratio (30 per cent) + Facebook fans (10 per cent) + Facebook engagement ratio ( 25 per cent).

With the aim of determining the professional relevance, a search engine was designed that was supplied with 20 relevant sector sources: magazines, blogs and reference sites. The engine was used to record the resulting number of items obtained in a search using key words and Boolean operators. For its part, the expert relevance was calculated by assigning a numerical value to the votes cast by the experts consulted to create the initial sample.

\section{Quantitative and Qualitative Analysis of the Innovations}

The second part of the method consisted of the qualitative analysis of each selected initiative, taking into account the four key areas of the media process: (1) the product or service; (2) the production and distribution processes; (3) the nature of the organisation or team; and (4) the commercial actions or strategies.

To record the innovations (Table 1), a Google form with two sections was designed. In the first, each innovation was separately coded. For each innovation, the degree of 
disruption was evaluated (radical or incremental, as explained further on), whether it had a technological basis or not (in-house or externally supplied), the area of innovation and a brief description of the solution provided. Once the search was finished, general information about each media outlet or media initiative was collected in the second section. The search was carried out by a group of four researchers over a period of six weeks (September and October 2014) through a coding guide. The researchers had previously tested the coding guide by analysing the innovations of two of the cases studied here.

This reliability test included a session in which the coding guide was explained, allowing any issues to be resolved. An individual analysis was then carried out with one of the two selected cases (specifically chosen to include innovations in the four areas analysed),

\section{TABLE 1}

Coding sheet of innovative initiatives

\begin{tabular}{|c|c|c|}
\hline \multirow[t]{3}{*}{ Basic information } & $\begin{array}{l}\text { Basis } \\
\text { Degree }\end{array}$ & $\begin{array}{l}\text { In-house technology } \\
\text { Outsourced technology } \\
\text { Non-technological } \\
\text { Incremental } \\
\text { Radical }\end{array}$ \\
\hline & $\begin{array}{l}\text { Aim } \\
\text { Solution or problem } \\
\quad \text { resolved }\end{array}$ & \\
\hline & Area & $\begin{array}{l}\text { Product or service } \\
\text { Production and distribution } \\
\text { processes } \\
\text { Company organisation } \\
\text { Marketing }\end{array}$ \\
\hline 1. Product or service & $\begin{array}{l}\text { 1.1. Themes } \\
\text { 1.2. Genres } \\
\text { 1.3. Multimedia } \\
\text { 1.4. Hypertext } \\
\text { 1.5. Architecture } \\
\text { 1.6. Multiplatform contents } \\
\text { 1.7. User-generated content } \\
\text { 1.8. Memory management } \\
\text { 1.9. Language }\end{array}$ & \\
\hline $\begin{array}{l}\text { 2. Production and } \\
\text { distribution }\end{array}$ & $\begin{array}{l}\text { 2.1. Production } \\
\text { 2.2. Distribution }\end{array}$ & $\begin{array}{l}\text { Content acquisition } \\
\text { News cycle } \\
\text { Relationship with the users } \\
\text { Diversification } \\
\text { Range }\end{array}$ \\
\hline 3. Organisation & $\begin{array}{l}\text { 3.1. Structure } \\
\text { 3.2. Initiatives for } \\
\text { innovation }\end{array}$ & \\
\hline 4. Marketing & 4.1. Product or service & $\begin{array}{l}\text { Advertising marketing } \\
\text { Direct marketing } \\
\text { Indirect or services marketing }\end{array}$ \\
\hline & $\begin{array}{l}\text { 4.2. Branding strategy } \\
\text { 4.3. Design and } \\
\text { presentation } \\
\text { 4.4. Online marketing } \\
\text { 4.5. External } \\
\text { communication }\end{array}$ & \\
\hline
\end{tabular}


followed by agreement between the four encoders of the coding carried out for each of the questionnaire's parameters. The four researchers' assessments tallied for most of the coded items. However, for those items where at least one did not concur, each disagreement was resolved by adding a clarifying note to the coding guide.

In the subsequent analysis, each media outlet was independently analysed by two of the researchers. For those scores that did not tally, a blind vote was conducted by all four researchers in order to guarantee greater reliability for the final result.

This test allowed us to resolve any doubts held by the encoders, to reformulate any points of the coding guide and to correct any errors in its application prior to analysing the cases.

Through this exploration, the encoders initially recorded 625 innovations among the 25 cases selected. The raw data were then reviewed to eliminate redundancies, inconsistencies or aspects of insufficient justification. The final number of valid innovations was reduced to 196.

The innovations were identified through three processes: (1) observation of products or production, distribution and marketing processes of the initiatives studied, and a comparison with their competitors; (2) interviews with the directors of the media outlets under analysis about aspects such as organisation; and (3) the use of secondary sources, such as other studies and published interviews.

For each innovation, two fields were completed: (1) a general assessment of the need or challenge; (2) a more specific solution. For example, the need to "differentiate the product through gamification" was resolved with "the use of the aesthetics and mechanics of video games in the treatment of the contents of an interactive product" or, in the case of the challenge "to guarantee source anonymity", "association as a collaborating member with a tool to provide information without the need for identification" was chosen.

The final part of the work consisted of numerically weighting each innovation in order to obtain an objective scale. For this, we opted to assign the same relevance to the four areas of innovation in line with the starting point, i.e. equally value the original solution given to a pending task that affects value creation of the media process. However, not all the innovations had the same impact and not all agents in a particular sector changed at the same time. We therefore chose to weight the "incremental degree" innovations, which involved a slight adaptation or improvement in the established temporal or geographical context, with 1 point. The "radical degree" innovations were considered to be those that were applied for the first time or that resulted in a substantial improvement over the pre-existing state; these were assigned 3 points.

Radical innovations were assigned a greater value than incremental innovations. Both types of innovation could have been coded as a continuum, but in our case, in order to create a comprehensive index according to the analysis carried out, we decided to give them a larger numerical value (3 versus 1). Evidently, this value could be questioned, but it can be justified by the fact that a disruptive innovation has a greater repercussion on the organisation itself in the reference market.

These two types of innovations had been implemented between July 2013 and July 2014 , which lies within the time period of this study. To compensate for those cases that were the first to innovate before July 2013, we created a further category, "earlier radical degree", assigning a value of 2 points to each innovation. The final total of each innovation in each case determined the definitive order of the selected 25 cases in the Index of Media Innovation. 


\section{Method Limitations}

During the various stages of the fieldwork and analysis, several methodological difficulties arose that introduced some limitations regarding the validity of part of the results.

Firstly, in the selection of the group of experts (20 in total), their experience and knowledge of the media sector were taken into account, which resulted in the selection of 10 academics and 10 professionals. However, the connection of some of the professionals with the media may have caused a conflict of interest with regard to choosing their list of innovative cases.

Among the parameters used to measure each media outlet's audience, we chose to use the Alexa ranking, as not all the websites of the media outlets analysed were indexed in other traffic-measuring systems such as ComScore. It could be argued that Alexa might not be the most exhaustive tool for website analysis. However, for the purposes of this study, it does allow homogenous results of the main websites of each case studied here to be obtained as the Alexa system provides information on them. Nevertheless, a system that aggregates the results of various indicators, such as ComScore, Alexa, OJD, etc., could have been used to avoid distortions. Similarly, with regard to the use of tools to measure the impact of social networks, other valid options for percentage distribution distinct from those used could have been employed.

The large number of innovations originally identified by the encoders in the 25 cases studied-625-contrasts with the result of the final quantified cases: 196 . The disparity between these figures is due to the fact that many of the coded innovations initially counted the same innovation in various areas. For example, a tool to interact with the audience may have been coded as an innovation under "service", "distribution" and "organisation". We therefore decided to code each innovation exclusively in the one area that best defined its impact on the media outlet with the aim of avoiding redundancies.

Similarly, assigning scores from 1 to 3 to each innovation-according to which an incremental innovation was awarded 1 point, an earlier radical innovation was assigned a score of 2 and a radical one, 3 points-was the most debatable criterion adopted in that other weightings could be established that were closer to those proposed here.

Finally, the analysis could have been improved through the use of interviews with those responsible for the innovations or the executives of each media company, with the aim of collecting information about other aspects that are more complicated to measure through media website analysis, such as the strategies used to improve products or services, the success of marketing channels or the business models implemented, as well as innovation in specific aspects of internal organisation.

\section{Results}

\section{Index of Media Innovation}

As a result of this study (Table 2), the Index of Media Innovation gathers the most innovative media initiatives in Spain in 2014: Fundación Civio (with 22 points), El Confidencial (19), Vis-à-Vis (19), eldiario.es (18) and Acuerdo (18). This classification highlights the innovation currently being implemented at the margins of the traditional news industry by digital native media outlets such as El Confidencial and eldiario.es; a nonprofit initiative such as Fundación Civio, which is based on specialised projects; Vis-à- 
Vis, an interactive magazine for iPads; and Acuerdo, which has developed new reporting formats.

This trend is continued in the following five cases: RTVE's Lab (17); Vizzuality (16), a start-up that focuses on the design and visualisation of news and that distances itself from the traditional concept of journalism; Infolibre (15), a freemium digital native outlet; Mongolia (13), a satirical/political magazine and Revista Don (12), a magazine for tablets.

Publication in paper version and brand image characterise the following initiatives: $L a$ Marea (11), Jot Down (10) and Panenka (10). Naukas (11) has succeeded in innovating in the publication of scientific news and The Objective (11) has remodelled news presentation through photographic selection. For their part, Yorokobu (8), Porcentual (7), Qué hacen los diputados (7), Politikon (6) and SportYou (6) demonstrate the capacity for innovation of the niche initiatives, although with more modest results.

The Index also includes minority projects: hyperlocal media outlets (Ara and GranadaiMedia); a website dedicated to science (Materia) and El Extrarradio, an innovating radio station that broadcasts high-quality content via podcasting.

\section{Area of Innovation}

Most of the innovations occur in the areas of product/service and production/distribution, followed closely by marketing. The area with the least number of initiatives is internal organisation for the reasons previously mentioned.

TABLE 2

Index of Media Innovation

\begin{tabular}{llcl}
\hline Position & \multicolumn{1}{c}{ Name } & Number of points & \\
1 & Civio & 22 & URL \\
2 & El Confidencial & 19 & civio.es \\
2 & Vis-à-Vis & 19 & elconfidencial.com \\
4 & Acuerdo & 18 & vis-a-vis.es \\
4 & eldiario.es & 18 & acuerdo.us \\
6 & Lab RTVE & 17 & eldiario.es \\
7 & Vizzuality & 16 & lab.rtve.es \\
8 & Infolibre & 15 & vizzuality.com \\
9 & Mongolia & 13 & infolibre.es \\
10 & Revista Don & 12 & revistamongolia.com \\
11 & La Marea & 11 & revistadon.com \\
11 & Naukas & 11 & lamarea.com \\
11 & The Objective & 11 & naukas.com \\
14 & Jot Down & 10 & theobjective.com \\
14 & Panenka & 10 & jotdown.es \\
16 & Yorokobu & 8 & panenka.org \\
17 & Porcentual & 7 & yorokobu.es \\
17 & Qué hacen los diputados & 7 & porcentual.es \\
19 & Politikon & 6 & quehacenlosdiputados.net \\
19 & SportYou & 6 & politikon.es \\
21 & Ara & 5 & sportyou.es \\
21 & El Extrarradio & 5 & ara.cat \\
23 & Granada iMedia & 4 & elextrarradio.com \\
23 & La Información & 4 & granadaimedia.com \\
25 & Materia & 3 & lainformacion.com \\
\hline & & & esmateria.com \\
\hline & & &
\end{tabular}


In the area of product and service (see Table 3), the leading innovations are those related to the presentation of contents through large full-screen formats. These outlets use hypertext in a novel way and organise the menus in the page itself-breaking with the usual formats-such that visual resources dominate over text.

Product and service innovations that directly affect user participation are associated with four areas: (1) the presence of the media outlet on social networks and the promotion of its channels; (2) the creation of narratives backed by gamification that require users' active participation; (3) the improvement of the comments system to create a quality community; and (4) production collaboration (crowdsourcing). Some of the initiatives are based on content customisation through the information and geographical location provided by the user. In other cases, innovative content is generated from users' comments and replies, such as interactive maps that gradually expand according to each user's interests.

Of itself, the management of social networks could not be classified as innovative. However, some of the media outlets have used these channels to encourage audience engagement. For example, the use of Spotify accounts integrated into the device improves the content through a multimedia experience and makes it easier for users to sign up to the outlet's music lists and to listen to and comment on them.

The main innovations in the area of distribution and production are those innovations that seek new ways of relating with clients/users as part of the media process. In a few cases, members enjoy special treatment in the comments section compared to

TABLE 3

Index of Media Innovation according to object of innovation

\begin{tabular}{|c|c|c|c|c|c|c|c|}
\hline Position & Name & Product & Production & Organisation & Marketing & Total & Points \\
\hline 1 & Civio & 6 & 9 & 0 & 7 & 15 & 22 \\
\hline 2 & El Confidencial & 7 & 7 & 0 & 5 & 15 & 19 \\
\hline 2 & Vis-à-Vis & 10 & 5 & 0 & 4 & 10 & 19 \\
\hline 4 & Acuerdo & 11 & 0 & 1 & 6 & 12 & 18 \\
\hline 4 & eldiario.es & 0 & 11 & 0 & 7 & 8 & 18 \\
\hline 6 & Lab RTVE & 10 & 2 & 2 & 3 & 14 & 17 \\
\hline 7 & Vizzuality & 9 & 6 & 0 & 1 & 14 & 16 \\
\hline 8 & Infolibre & 7 & 5 & 0 & 3 & 10 & 15 \\
\hline 9 & Mongolia & 5 & 1 & 3 & 4 & 7 & 13 \\
\hline 10 & Revista Don & 6 & 3 & 0 & 3 & 8 & 12 \\
\hline 11 & La Marea & 0 & 4 & 5 & 2 & 7 & 11 \\
\hline 11 & Naukas & 5 & 0 & 1 & 5 & 7 & 11 \\
\hline 11 & The Objective & 7 & 1 & 1 & 2 & 10 & 11 \\
\hline 14 & Jot Down & 4 & 3 & 0 & 3 & 9 & 10 \\
\hline 14 & Panenka & 4 & 1 & 0 & 5 & 7 & 10 \\
\hline 16 & Yorokobu & 3 & 2 & 0 & 3 & 7 & 8 \\
\hline 17 & Porcentual & 4 & 0 & 0 & 3 & 3 & 7 \\
\hline 17 & $\begin{array}{c}\text { Qué hacen los } \\
\text { diputados }\end{array}$ & 2 & 5 & 0 & 0 & 6 & 7 \\
\hline 19 & Politikon & 2 & 3 & 0 & 1 & 4 & 6 \\
\hline 19 & SportYou & 2 & 4 & 0 & 0 & 4 & 6 \\
\hline 21 & Ara & 1 & 2 & 0 & 2 & 5 & 5 \\
\hline 21 & El Extrarradio & 1 & 2 & 1 & 1 & 5 & 5 \\
\hline 23 & Granada iMedia & 2 & 1 & 0 & 1 & 4 & 4 \\
\hline 23 & La Información & 4 & 0 & 0 & 0 & 2 & 4 \\
\hline 25 & Materia & 1 & 0 & 0 & 2 & 3 & 3 \\
\hline
\end{tabular}


average users. Regarding production, some of the innovations are related to the creation of specialised databases on information of public interest (sentences, juries or indictable offences), and are open to crowdsourcing and collaborative improvements. A few of the outlets innovate in the creation of spaces specifically for user participation.

More than half of the media companies analysed did not have any innovative characteristic in terms of organisation. However, one of the most innovative cases is that of eldiario.es, a media outlet in the form of a co-operative made up of journalists and readers who, as members, participate in the company's decision-making processes. The design and organisation of these new companies' work environments do not entirely correspond to traditional references. If media products are changing, it is logical that work environments, organisation and professional routines are also changing. In another case - Acuerdo-each worker chooses a timetable they consider convenient and which is based on the trust that exists between employer and employee. Some of its staff regularly works away from the office on flexitime.

The category of organisation includes the analysis of other features such as workflow structure, team composition and the use of technological tools. In this regard, two initiatives included in the Index have created R\&D laboratories made up of multidisciplinary teams who work together in the development of data visualisation, interactive projects or on the improvement of the user experience. For their part, those innovations concerned with the acquisition of external technologies to improve workflow are also worth noting. Outlets use them to gain flexibility, thereby facilitating a fluid, horizontal communication among media professionals.

\section{TABLE 4}

Index of Media Innovation according to degree of innovation

\begin{tabular}{|c|c|c|c|c|c|c|}
\hline Position & Name & Incremental & Radical & Older radical & Total & Points \\
\hline 1 & Civio & 11 & 3 & 1 & 15 & 22 \\
\hline 2 & El Confidencial & 12 & 1 & 2 & 15 & 19 \\
\hline 2 & Vis-à-Vis & 3 & 2 & 5 & 10 & 19 \\
\hline 4 & Acuerdo & 9 & 3 & 0 & 12 & 18 \\
\hline 4 & eldiario.es & 3 & 5 & 0 & 8 & 18 \\
\hline 6 & Lab RTVE & 11 & 0 & 3 & 14 & 17 \\
\hline 7 & Vizzuality & 13 & 1 & 0 & 14 & 16 \\
\hline 8 & Infolibre & 5 & 0 & 5 & 10 & 15 \\
\hline 9 & Mongolia & 4 & 3 & 0 & 7 & 13 \\
\hline 10 & Revista Don & 6 & 2 & 0 & 8 & 12 \\
\hline 11 & La Marea & 3 & 0 & 4 & 7 & 11 \\
\hline 11 & Naukas & 4 & 1 & 2 & 7 & 11 \\
\hline 11 & The Objective & 9 & 0 & 1 & 10 & 11 \\
\hline 14 & Jot Down & 8 & 0 & 1 & 9 & 10 \\
\hline 14 & Panenka & 5 & 1 & 1 & 7 & 10 \\
\hline 16 & Yorokobu & 6 & 0 & 1 & 7 & 8 \\
\hline 17 & Porcentual & 1 & 2 & 0 & 3 & 7 \\
\hline 17 & Qué hacen los diputados & 5 & 0 & 1 & 6 & 7 \\
\hline 19 & Politikon & 3 & 1 & 0 & 4 & 6 \\
\hline 19 & SportYou & 3 & 1 & 0 & 4 & 6 \\
\hline 21 & Ara & 5 & 0 & 0 & 5 & 5 \\
\hline 21 & El Extrarradio & 5 & 0 & 0 & 5 & 5 \\
\hline 23 & Granada iMedia & 4 & 0 & 0 & 4 & 4 \\
\hline 23 & La Información & 0 & 0 & 2 & 2 & 4 \\
\hline 25 & Materia & 3 & 0 & 0 & 3 & 3 \\
\hline
\end{tabular}


With regard to marketing, a few of the media outlets seek new revenue streams through innovative brand resources, such as the organisation of thematic events or meetings with their members to share ideas about editorial direction. Other innovative cases offer services beyond the creation of an editorial product. Some provide training courses, while others offer public relations services to local businesses.

\section{Degree of Innovation}

As explained in the Methods section, the degree of innovation assigned to each initiative reflects whether it is an incremental or radical (old or new) innovation, with its corresponding score. This score is applied as a function of the study's spatial-temporal framework. Among the main results, it is notable that most of the radical innovations come from pure digital players who innovate in user management, content specialisation, the introduction of interactive formats and the organisation of events.

In general terms, incremental innovations (141) prevail over radical innovations (26). Most changes introduced into the Spanish media companies represent small advances over the pre-existing initiatives from the active adaptation period (2002-2008). The number of earlier radical innovations (29), meanwhile, demonstrates that quality innovations took place before July 2013, the start of our study. To a certain degree, this fact reveals that innovation is not a recent phenomenon within the Spanish media industry (Table 4) .

\section{TABLE 5}

Index of Media Innovation according to technological basis of innovation

\begin{tabular}{|c|c|c|c|c|c|c|}
\hline Position & Name & In-house & External & Non-technological & Total & Points \\
\hline 1 & Civio & 4 & 2 & 16 & 15 & 22 \\
\hline 2 & El Confidencial & 2 & 7 & 10 & 15 & 19 \\
\hline 2 & Vis-à-Vis & 10 & 6 & 3 & 10 & 19 \\
\hline 4 & Acuerdo & 13 & 1 & 4 & 12 & 18 \\
\hline 4 & eldiario.es & 0 & 6 & 12 & 8 & 18 \\
\hline 6 & Lab RTVE & 10 & 4 & 3 & 14 & 17 \\
\hline 7 & Vizzuality & 13 & 3 & 0 & 14 & 16 \\
\hline 8 & Infolibre & 0 & 8 & 7 & 10 & 15 \\
\hline 9 & Mongolia & 0 & 1 & 12 & 7 & 13 \\
\hline 10 & Revista Don & 1 & 11 & 0 & 8 & 12 \\
\hline 11 & La Marea & 0 & 2 & 9 & 7 & 11 \\
\hline 11 & Naukas & 0 & 6 & 5 & 7 & 11 \\
\hline 11 & The Objective & 2 & 3 & 6 & 10 & 11 \\
\hline 14 & Jot Down & 0 & 7 & 3 & 9 & 10 \\
\hline 14 & Panenka & 0 & 2 & 8 & 7 & 10 \\
\hline 16 & Yorokobu & 0 & 5 & 3 & 7 & 8 \\
\hline 17 & Porcentual & 1 & 3 & 3 & 3 & 7 \\
\hline 17 & Qué hacen los diputados. & 1 & 2 & 4 & 6 & 7 \\
\hline 19 & Politikon & 0 & 1 & 5 & 4 & 6 \\
\hline 19 & SportYou & 0 & 0 & 6 & 4 & 6 \\
\hline 21 & Ara & 1 & 0 & 4 & 5 & 5 \\
\hline 21 & El Extrarradio & 0 & 3 & 2 & 5 & 5 \\
\hline 23 & Granada iMedia & 0 & 1 & 3 & 4 & 4 \\
\hline 23 & La Información & 0 & 4 & 0 & 2 & 4 \\
\hline 25 & Materia & 0 & 1 & 2 & 3 & 3 \\
\hline
\end{tabular}




\section{Technological Basis of the Innovation}

This section identifies whether a specific innovation has a technological basis and, if so, whether it is in-house technology or external to the media outlet concerned. A total of 87 non-technological innovations were recorded (with a score of 130 points) and 109 technological (147 points). Similarly, foremost among the technologies were those based on external technology ( 89 points) versus the 58 points for the innovations based on inhouse software (Table 5) .

The case foremost for its technological innovations is the technology-based start-up Vizzuality, which moved into journalism to broaden its brand scope. Meanwhile, there are two media pure players that have had an impact on their content management systems and on the creation of interactive graphics that focus on financial information.

\section{Conclusion: The Extent of Media Innovation in Spain}

This study shows that, in Spain, innovation occurs at the margins of the traditional news industry, since no legacy media outlet appears among the most innovative. By contrast, foremost among the latter are digital media companies, niche media outlets, foundationbased initiatives, tablet magazines and technology start-ups. However, whilst it is possible to innovate independently of the type of platform, as demonstrated by the presence of print and broadcast outlets, most initiatives included in the Index of Media Innovation are internet-based or consider it an indispensable ally. The saying "necessity is the mother of invention" is apposite here: the majority of the most innovative examples were set up by those who lost their job as a result of the financial crisis that has devastated Spain since 2008.

The cases listed in the Index are not those with the largest audience, nor those that provide greater quality content. Audience size and information quality are parameters that are not reflected in the Index's measurements, which essentially records innovations. Nevertheless, the various digital native media companies that lead the Index have experienced considerable success. Some of the more recent initiatives, such as eldiario.es and infoLibre, have introduced interesting membership models that encourage user participation. Other projects have emerged from the not-for-profit media services sector, with flexible structures and powered by crowdfunding campaigns.

Regarding the specific target, most of the innovations concern product/service, production/distribution or marketing, and less so company organisation. Foremost among the most innovative outlets were those that go to great efforts to involve users in content production and distribution and in the final result, such that users enjoy greater interaction with the company. More technological innovations were recorded than non-technological, indicating that while innovation is not necessarily associated with technology, it is an important driver of change. Similarly, in the specific case of technological cases, those based on external technology prevail, highlighting the difficulty in developing in-house digital tools and systems.

The methodology aims to help clarify the concept of innovation in a media sector that, as seen in a review of the literature, is still somewhat vague, thereby making it difficult to agree on the definition of the concept, establish its genres or analyse its practical implications. We believe that, despite their limitations, the methodological tools used here allow the measurement and evaluation of the extent of the innovations in cases analysed in a specific market. The method used to generate the Index of Media Innovation described 
here could be applied to other countries and replicated in other studies of innovation in different media markets, including comparisons between sectors. Therefore, a series of structural parameters that could affect the degree of media innovation should be taken into consideration: the country's media policy, the degree of media concentration, the size of the markets, the level of economic growth, technological development (e.g. internet and broadband penetration) and traditions of media culture. Innovations should be measured over periods of more than two years in order to detect their scale and effectiveness. Similarly, long-term studies should be conducted that enable the evolution of particular innovations to be measured over an extended period of time.

Our results reveal that innovation within the media industry can affect the product, service and media process, the production and distribution phases, workflow organisation and end-product marketing. The concept of innovation proposed here is based on the need to find innovative solutions in the face of the challenges that determine the modus operandi of both media professionals and users. Therefore, any vision of innovation that is limited to the introduction of technologies or anchored in the concept of novelty for the sake of novelty is circumvented.

This analysis has limitations, of course, when evaluating specific areas, such as organisation, parameters related to product improvement, the development of Web analytics tools or the effectiveness of social engagement. It would be interesting to analyse these aspects in further detail in future studies through personalised interviews that broaden the most qualitative facets of this study, and to refine the measurement tools to eliminate any possible errors. Similarly, it would be interesting to widen the research through longitudinal analyses that measure the effectiveness of innovations among the media enterprises analysed. Furthermore, it would be of interest to conduct a second phase of interviews with the journalists involved in the various innovations, in order to confirm the scope of the results.

As a result of our research, the Index of Media Innovation reveals that measuring this process should be carried out in greater depth in order to improve our knowledge of the changes occurring in an industry that is experiencing a period of disruptive transition (Storsul and Krumsvik 2013). Further studies in other reference media sectors or markets, with different scopes and structural factors, will contribute to bringing these innovation indicators to general use and to examine to what degree the advances impact on the future of journalism.

\section{DISCLOSURE STATEMENT}

No potential conflict of interest was reported by the authors.

\section{NOTES}

1. See http://www.twitonomy.com/.

2. See http://likealyzer.com/.

\section{REFERENCES}

Anderson, Chris W., Emily Bell, and Clay Shirky. 2012. Post-industrial Journalism: Adapting to the Present: a Report. Columbia University. Tow Center for Digital Journalism. Accessed 
October 30, 2015. http://towcenter.org/research/post-industrial-journalism-adapting-tothe-present-2/.

APM. Asociación de la Prensa de Madrid. 2015. Informe Anual de la Profesión Periodística 2015. Madrid: APM.

Baregheh, Anahita, Jennifer Rowley, and Sally Sambrook. 2009. "Towards a Multidisciplinary Definition of Innovation." Management Decision 47 (8): 1323-1339. doi:10.1108/ 00251740910984578.

Baumann, Sabine. 2013. "Adapting to the Brave New World. Innovative Organisational Strategies for Media Companies." In Media Innovation. A Multidisciplinary Study of Change, edited by Tanja Storsul and Arne H. Krumsvik, 77-92. Göteborg: Nordicom.

Bleyen, Valèrie-Anne, Sven Lindmark, Heritiana Ranaivoson and Pieter Ballon. 2014. "A Typology of Media Innovations: Insights from an Exploratory Study." The Journal of Media Innovations 1 (1): 28-51.

Boczkowski, Pablo J. 2004. Digitizing the News: Innovation in Online Newspapers. Cambridge, Massachusetts: The MIT Press.

British Broadcasting Corporation. 2015. Future of News, January 2015 Report. Accessed October 30, 2015 http://newsimg.bbc.co.uk/1/shared/bsp/hi/pdfs/29_01_15future_of_news.pdf.

Bruno, Nicola, and Rasmus K. Nielsen. 2012. Survival is Success. Journalistic Online Startups in Western Europe. Oxford: The Reuters Institute for the Study of Journalism.

Bruns, Axel. 2014. "Media Innovations, User Innovations, Societal Innovations." The Journal of Media Innovations 1 (1): 13-27.

Cardoso, Gustavo, and José Moreno. 2015. "Technology Management and Business Models." In Managing Media Firms and Industries: What's so Special About Media Management?, edited by Gregory Ferrell Lowe and Charles Brown, 37-52. New York: Springer.

Carlson, Matt and Nikki Usher. 2015. "News Startups as Agents of Innovation." Digital Journalism 0 (0): 1-19.

Carvajal, Miguel, Félix Arias, Samuel Negredo, and Avelino Amoedo. 2015. "Aproximación Metodológica al Estudio de la Innovación en Periodismo." Observatorio (OBS*) 9 (3): 15-31.

Carvajal, Miguel, Jose A. García-Avilés, and Jose L. González. 2012. "Crowdfunding and Non-profit Media: The Emergence of New Models for Public Interest Journalism." Journalism Practice 6 (5-6): 638-647.

Christensen, Clayton M. 1997. The Innovator's Dilemma: When New Technologies Cause Great Firms to Fail. Boston, MA: Harvard Business School Press.

Christensen, Clayton M., David Skok, and James Allworth. 2012. "Breaking News. Mastering the Art of Disruptive Innovation in Journalism." Nieman Reports 66 (3): 6-20.

Dal Zotto, Cinzia, and Hans Van Kranenburg, eds. 2008. Management and Innovation in the Media Industry. Cheltenham, UK: Edward Elgar.

Dogruel, Leyla. 2013. "Opening the Black Box. The Conceptualizing of Media Innovation." In Media Innovation. A Multidisciplinary Study of Change, edited by Tanjaa Storsul and Arne H. Krumsvik, 29-44. Göteborg: Nordicom.

Dogruel, Leyla. 2014. "What is so Special about Media Innovations? A Characterization of the Field." The Journal of Media Innovations 1 (1): 52-69.

Eurostat. 2012. Community Innovation Survey. Accessed February 11, 2016. http://ec.europa.eu/ eurostat/web/microdata/community-innovation-survey.

Fagerberg, Jan. 2004. "Innovation: A Guide to the Literature." In The Oxford Handbook of Innovation, edited by Jan Fagerberg, David Mowery and Richard Nelson, 11-28. New York: Oxford University Press. 
Franklin, Bob. 2014. "The Future of Journalism: In an Age of Digital Media and Economic Uncertainty." Journalism Practice 8 (5): 469-487.

García-Avilés, José A. 2012. "Innovation Management in Crossmedia Production: Leading change in the Newsroom." In Crossmedia Innovations. Texts, Markets, Institutions, edited by Indrek Ibrus and Carlos A. Scolari, 259-276. Frankfurt: Peter Lang.

García-Santamaría, José V., María D. Clemente, and María López. 2013. “The Relationship between the Organisation of Digital Newsrooms in Spain and the Emergence of New Models for Journalism." Textual \& Visual Media 6: 35-54.

van Kerkhoven, Marco, and Piet Bakker. 2014. "The Hyperlocal in Practice: Innovation, Creativity and Diversity." Digital Journalism 2 (3): 296-309.

Krumsvik, Tanja, and Arne H. Storsul, eds. 2013. Media Innovations: A Multidisciplinary Study of Change. Göteborg: Nordicom.

Küng, Lucy. 2013. "Innovation, Technology and Organisational Change." In Media Innovation. A Multidisciplinary Study of Change, edited by Tanjaa Storsul and Arne H. Krumsvik, 9-12. Göteborg: Nordicom.

Linke, Anne, and Ansgar Zerfass. 2012. "Future Trends in Social Media Use for Strategic Organisation Communication: Results of a Delphi study." Public Communication Review 2: 17-29.

Llorens, Carles, Helena P. Grau, and Virginia Luzón. 2013. "Mapping Digital Media and Journalism in Spain." Anàlisi: Quaderns de Comunicació i Cultura 49: 43-64.

López, Xosé, and Xosé Pereira Coords. 2010. Convergencia Digital. Reconfiguración de los Medios de Comunicación en España. Santiago: Universidad de Santiago.

Napoli, Philip. 2014. Measuring Media Impact. The Norman Lear Center. Accessed October 24, 2015. http://www.learcenter.org/pdf/measuringmedia.pdf.

Nee, Rebeca C. 2013. "Creative Destruction: An Exploratory Study of How Digitally Native News Non-profits Are Innovating Online Journalism Practices." International Journal on Media Management 15 (1): 3-22.

Nguyen, An. 2008. "Facing 'The Fabulous Monster': The Traditional Media's Fear-Driven Innovation Culture in the Development of Online News." Journalism Studies 9 (1): 91-104.

OECD Organisation for Economic Co-operation and Development. 2005. Oslo Manual: Guidelines for Collecting and Interpreting Innovation Data, 3rd Edition. Paris: OECD Publishing.

O'Sullivan, David, and Lawrence Dooley. 2008. Applying Innovation. Thousand Oaks: Sage Publications, Inc.

Robinson, Sue. 2011. "Journalism as Process: The Organizational Implications of Participatory Online News." Journalism \& Communication Monographs 13 (3): 137-210.

Sádaba, Charo, José A. García Avilés, and María P. Martínez-Costa. 2016. Innovación y Desarrollo de los Cibermedios en España. Pamplona: Eunsa.

Salaverría, Ramón Coord. 2005. Cibermedios. El Impacto de Internet en los Medios de Comunicación en España. Sevilla: Comunicación Social.

Schroeder, Roland. 2004. "Interactive Info Graphics in Europe -added value to online mass media: a preliminary survey." Journalism Studies 5 (4): 563-570.

Schumpeter, Joseph. 1975. Capitalism, Socialism and Democracy. New York: Harper.

Siapera, Eugenia. 2012. Understanding New Media. London: Sage.

Spyridou, Lia-Paschalia, Maria Matsiola, Andreas Veglis, George Kalliris, and Charalampos Dimoulas. 2013. "Journalism in a State of Flux: Journalists as Agents of Technology Innovation and Emerging News Practices." International Communication Gazette 75 (1): 76-98.

Steensen, Steen. 2009. "What's Stopping Them? Towards a Grounded Theory of Innovation in Online Journalism." Journalism Studies, 10 (6): 821-836. doi:10.1080/14616700902975087. 
Storsul, Tanja, and Arne H. Krumsvik. 2013. "What is Media Innovation?" In Media Innovation. A Multidisciplinary Study of Change, edited by Tanjaa Storsul and Arne H. Krumsvik, 13-26. Göteborg: Nordicom.

The New York Times. 2014. The New York Times Innovation Report. Accessed October 19, 2015. http://visualdays.no/files/2014/05/224608514-The-Full-New-York-Times-InnovationReport.pdf.

van der Wurff, Richard, and Klaus Schönbach. 2014. "Audience Expectations of Media Accountability in the Netherlands." Journalism Studies 15 (2): 121-137. doi:10.1080/1461670X.2013. 801679.

Weiss, Amy S., and David Domingo. 2010. "Innovation Processes in Online Newsrooms as Actornetworks and Communities of Practice." New Media and Society 12 (7): 1156-1171.

Westlund, Oscar, and Arne H. Krumsvik. 2014. "Perceptions of Intra-Organizational Collaboration and Media Workers' Interests in Media Innovations." The Journal of Media Innovations 1 (2): 52-74.

Westlund, Oscar, and Seth Lewis. 2014. "Agents of Media Innovations: Actors, Actants, and Audiences." The Journal of Media Innovations 1 (2): 10-35.

José A. García-Avilés (author to whom correspondence should be addressed), Department of Ciencias Sociales y Humanas, University Miguel Hernández, Spain. E-mail: jose. garciaa@umh.es

Miguel Carvajal-Prieto, Department of Ciencias Sociales y Humanas, University Miguel Hernández, Spain. E-mail: mcarvajal@umh.es

Alicia De Lara-González, Department of Ciencias Sociales y Humanas, University Miguel Hernández, Spain. E-mail: a.lara@umh.es

Félix Arias-Robles, Department of Ciencias Sociales y Humanas, University Miguel Hernández, Spain. E-mail: farias@umh.es 